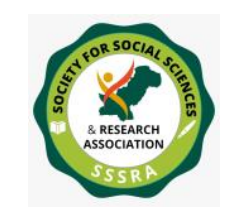

\title{
Resource Curse and Political \& Economic Transition in Central Asia
}

\author{
Dr. Uzma Siraj \\ Assistant Professor \\ Department of Pakistan Studies \\ Federal Urdu University Islamabad \\ uzma.siraj@funast.edu.pk \\ Dr. Faisal Javaid \\ Assistant Professor \\ Department of International Relations \\ FUUAST, Karachi-Pakistan \\ faisal.javaid@fuuat.edu.pk
}

\begin{abstract}
The role of rich hydrocarbon resources in the political \& economic development of the Central Asian states has raised a lot of interest among scholars of international relations and Political Economy. The unsuccessful transition towards the capitalist economy and democratic political system have included them in the category of states affected by the resource curse. The prime purpose of this study is to examine the Resource Curse theory in the context of the Central Asia region to comprehend its impacts on the economic and political transition of the region. The study argues that ever since the region gained independence in 1991, the rich natural resource endowment of the region could not produce any substantial transformation in the political and economic landscape of the region. Despite their GDP and per capita growth, Politics and economy are completely divergent domains. Economic development, democratization, and nation-building are still detached spheres in Central Asia. A highly centralized political and economic system along with a predatory system of financial regulations and vested interests and heavy dependence on natural resource export instead of taxes reinforce the argument. The theory of resource curse provides a
\end{abstract}




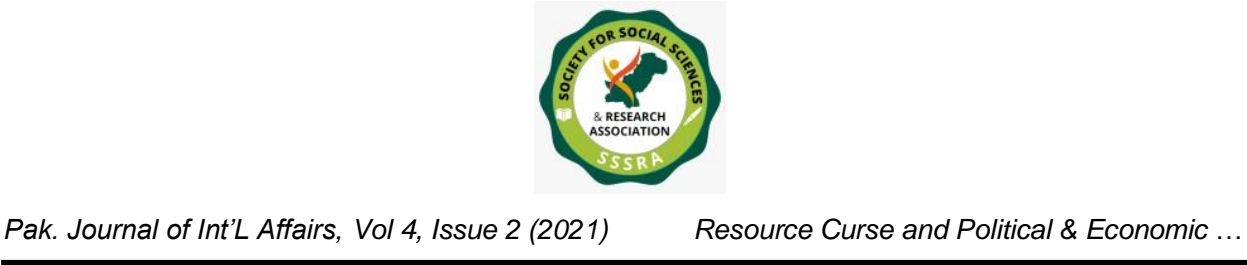

suitable theoretical tool to analyze the impotence of resource-rich states to establish a strong democratic base.

Key Word: Central Asia, Political Economy, Resource Curse, Regime stability, Centralized economy, Authoritarianism, Dutch Disease.

\section{Introduction}

Politics and economics are two concomitant phenomena of International Relations. The Optimistic equation presented in the Modernization literature of the previous century comprehends that there is an undeniable link between democratic stability and economic development (Leiras, et al. 2014). Democratization is a duplicitous process, largely depends upon the economic structure and its subsequent economic development. It works as a prerequisite for regime stability (Ekiert 1991). This emerged as a crucial fact with the emergence of the liberal world order after the fall of communism in the late twentieth century. The disintegration of the communist world and the independence of dozen of states instigated a keen interest in the analysis of democracy and its critical relationship with the economic structure (Doorenspleet, 2008). This is the time associated with the revival of Modernization theory when a wave of democratization was anticipated in almost $60 \%$ of states as a consequence of the triumph of Capitalism and its adoption in the communist world (Smith \& Jones, 2015). However, these expectations floundered in the former Soviet states of Central Asia. The threat of the retreat of democracy emerged as the biggest concern ending the initial invigoration.

Central Asian states could not draw a line between their obsolete system and political ideals for democracy and the economic system of Capitalism. Thus, their experiments with the establishment of democracy and the new economic model remained a puzzle for them and the world. This disorientation led them to establish non-democratic authoritarian regimes despite bringing market liberalization at the domestic level (Rustemova, 2010). Central Asian states present an interesting case study for analyzing such observation. The five former Soviet republics are mostly called hybrid regimes politically and resource-based economies due to their overreliance on natural resources for their economic development (Omelicheva M. Y., 2013). Before advancing this analysis to the next level it is pertinent to have a quick look at the political and economic conditions of the Central Asian republics under the communist regime and their political structure in the aftermath of their separation from the Soviet Union. This study, through a comparative analysis of political and economic conditions of the Central Asian republics at the time of their 


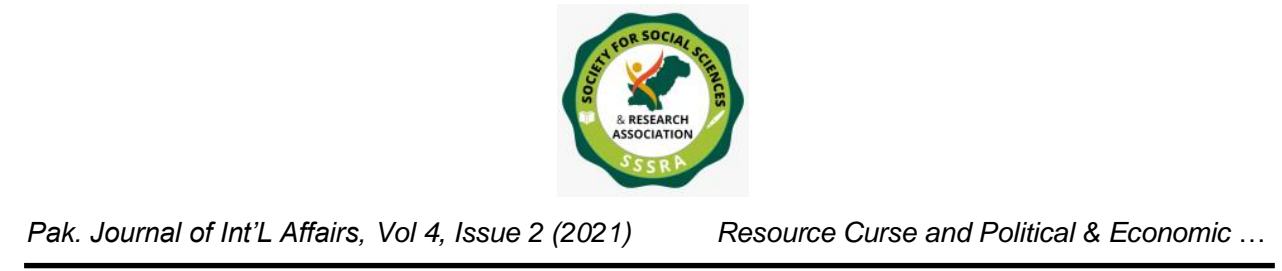

independence and after 25 years, would examine the impact of the natural resource curse over them.

\section{Pre Independence Economic Conditions of Central Asia}

The disintegration of the USSR in 1991 brought with it the two major challenges of independence for the five newly established Central Asian states. It includes political transition towards democracy and nation-building as well as the economic transition from Soviet-style centralized economy to an open market economy (Pomfret, 2006). The Soviet-era economic conditions of all regional states are not different from each other except their resource base. Three regional states of Kazakhstan, Turkmenistan, and Uzbekistan's mineral wealth and the hydroelectrical potential of Tajikistan and Kyrgyzstan remained an important factor in their economic contribution to the Soviet economy. In a centralized economic structure, Moscow's role in economic decision-making was decisive (Pomfret, 2006) and the role of Central Asian republics remained limited to raw material suppliers. The following overview of the economic structure and economic conditions of the former republics during the Soviet era will set the stage to understand their post-independent economic and political development.

Ever since their breakup from the former USSR, Kazakhstan remained a close associate of the Russian Federation during the first decade. It not only inherited the centrally planned economic system from its predecessor but also derived its insolvent economic structure and its problems like falling investment, backward industrial setup, and service sector, underdeveloped agriculture, concentrated production system, and indigent infrastructure. The centralized economic decisionmaking was the root cause and major obstacle in the development of the regional economy despite its rich mineral resource base. In addition to the inherited problems, scant knowledge, and the dearth of experienced experts of the open market economy made the transition phase worse. Other problems include ecological issues related to drying the Aral Sea, contamination of water from industrial pollutants, and nuclear waste in the selected testing areas of Kazakhstan (Buranbayeva, 1996).

As far as Turkmenistan's economic conditions are concerned, it used to be the most backward republic of the region during the communist era. Its status was too limited to raw material suppliers. Earlier, cotton production was the major source of revenue, thanks to the irrigation system built through Karakum Canal. Later, with the exploration of Natural gas during the last decade of the USSR, the government's 


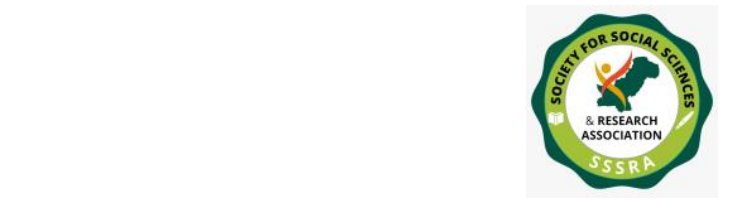

Resource Curse and Political \& Economic ...

focus shifted on energy resources extraction from the republic (Pomfret \& Anderson, 2001).

Unlike the above-mentioned energy-rich states, Tajikistan used to have more potential in hydroelectric production. It remained one of the abaft states in the former USSR. Until the first half of the previous century, Tajikistan was kept deprived of major communication infrastructure along with one of the highest unemployment levels in the whole USSR. (Tajikistan History/ Nationencyclopedia, 2017). Consequently, it had the lowest standards of living and a backward education system. Before independence, cotton was the most important raw material produced and delivered from Tajikistan. Moscow used to assign different economic roles to its states. Other natural resources produced here included gold, aluminum, and uranium. Tajikistan's southern flank was largely ignored in economic development. The Communist elite and the local clans in the northern province of Khujand used to have very close ties and thus played a decisive role in economic matters (Tajikistan History/ Nationencyclopedia, 2017).

Similarly, Kyrgyzstan did not have a rich mineral resource base but it held some valuable water reservoirs. The fertile land around the Amu Darya and the Syr Darya region was rich in agricultural production. However, due to the lack of attention, Kyrgyz share in total agricultural output remained under 1 percent (Buyers, 2003). Livestock development was more fixated and farming was largely ignored.

Uzbekistan presents a similar story and similar status as a resource purveyor. Thank to its high-yielding soil, it was among the major cotton-producing regions in Moscow during the Soviet era. An extensive policy was developed to boost its production. Cotton producers were provided with all resources technical and financial assistance, including loans, harvesters, ginneries and excavators, pumps, and generators (Melvin, 2000). Cotton focused Uzbek economy created cotton monoculturalism. Such a pervasive policy to raise cotton yield augmented its share in the total economy of the republic to $70 \%$. Cotton focused Uzbek economy created cotton monoculturalism. And it emerged as the White Gold of the Uzbek economy (Khan, 2008).

\section{Political Landscape After Independence}

The political landscape was not much different. The political authority was monopolized in the hands of Communist elites, who used to uphold the power in the 


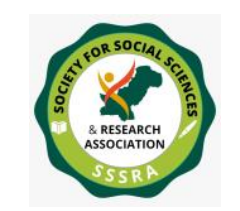

Resource Curse and Political \& Economic ...

process of economic and political transition. Political authority was synonymous with having a property with financial significance.

Similarly, it was assumed that political authority and economic power are inseparable. Sharing political authority is parallel to sharing economic powers and vise versa. Thus, ruling elites do not believe in power-sharing (Mclean W. , 2015). Despite the politico-economic transition, this paradigm prevailed to this day in Central Asia. It strengthened the political elites of these states and consecrated the few individuals with lasting rule. It eventuated in only a few regime changes during the last three decades. The only regional state where two regime change has occurred is Kyrgyzstan (Cummings, 2010). The sustainability of regimes in these states poses some serious questions about their support base. In a region where the cult of personality is more prevalent but not much popular, how a regime can maintain a solid support base needs investigation. The Central Asian states, on the one hand, have been struggling with the political transition towards democracy, on the other hand, authoritarianism is regarded as the only possible way for the advancement towards the establishment of democracy (Kubicek, Authoritarianism in Central Asia: Curse or Cure?, 1998). Multiple factors are responsible for this paradoxical situation. It includes prevalent authoritative political structure, debilitated civil society, and communist-style structure of bureaucracy (Mclean, 2015). In such a situation, the ruling political elite believes that by commanding the financial tools of the state is necessary for upholding political clout.

This study examines the question, how an authoritative political elite maintains its control and remains in power with the switched economic doctrine. Therefore this paper argues the notion that it is not possible to discern the political implications of this particular political structure of the Central Asia region without deeply looking at the economic facet. The economic structure of the region necessarily has some political ramifications. It is especially true in the case of Central Asia, where a huge reliance on natural resources like hydrocarbon and agriculture for economic development has made the government elite establish a close relationship with the related business clans, consisting of the raw material supplier (Mclean, 2015). In addition, the raw material suppliers are sympathetically inclined towards the prevailing authoritarian regimes. It constitutes an enduring relationship between the high-level bureaucracy \& the business elite and it is considered to be very important for the political stability in the CA states, thwarting any chances of accountability (Omelicheva, 2015).

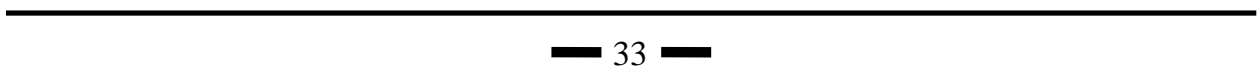




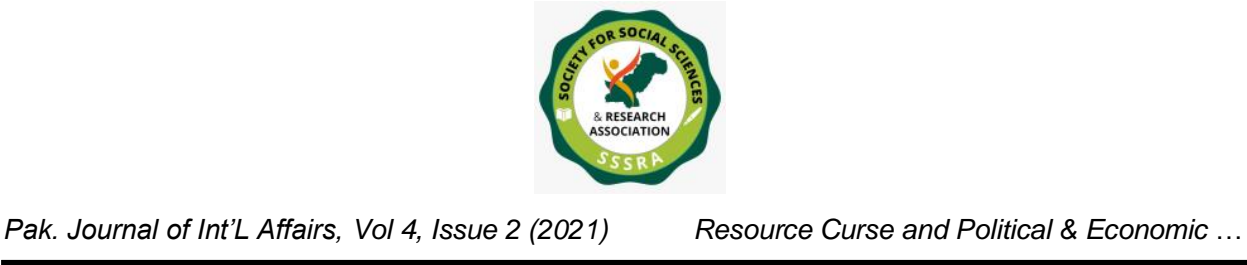

The theory of resource curse presents a good explanation of such phenomena and contends that it is hard for a state-dependent on the export of raw material to lay down the foundation of a stable democratic system. The main factor behind this is the short-term financial gains that they achieve through commodity export (Markowitz, 2013). Eventually, it drives toward fluctuation in the development and growth of the economy. It is evident in the unstable growth rate of GDP over the last two decades in the Central Asia region (Rumer, 2005). The following table further elaborates on this fact.

Table 1: Unstable GDP Growth since the Mid 1990s.

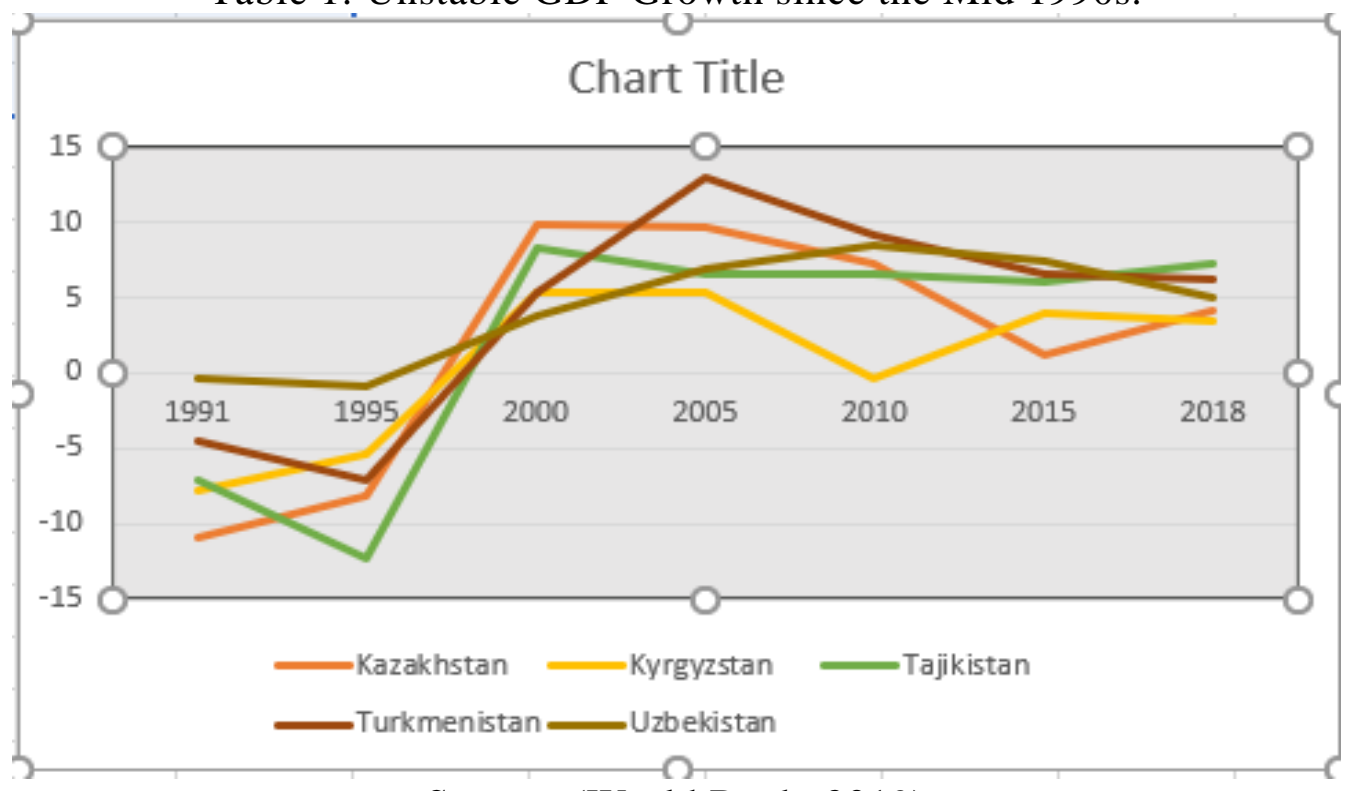

Source: (World Bank, 2019)

In this scenario, it proves hard to provide financial gains to the masses in an appropriate manner. Notwithstanding the fact, society is sluggish in demanding accountability. It is assumed that the existing bond between the bureaucratic elite and business community, determines the political outcomes in the region. The resource curse theory elaborates on this phenomenon in a perfect way (Luong, 2010). It demonstrates a causal relationship between governance and tax revenues. A very modest fraction of the national income in the Central Asian states is generated through taxes (Kunal, 2014). They are overwhelmingly reliant on the export of energy resources and other raw materials for their national income (Asian Development Bank, 2019). Moreover, the generated income is redistributed in the 


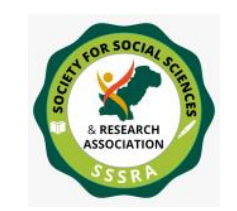

Pak. Journal of Int'L Affairs, Vol 4, Issue 2 (2021)

Resource Curse and Political \& Economic ...

two dominant political and economic elites like the bureaucratic elite and the business clans who run the whole mechanism of production and export of raw material. This turns out to be the major cause of the meager demand for accountability. In addition, It is the biggest impediment in establishing the marketoriented economic system. The export of raw material export brings with it only short-term financial gains (Dowling, 2006). As a result, It is hard to find a stable growth pattern in the GDP growth of the Central Asian states, as well as their inability, is exposed to develop a strong democratic system. In comparison, a better governance model is found in the countries where tax collection makes a strong contribution to the national income (Moore, 2004). It greatly enhances the ability of the tax payer's to demand strict accountability. It becomes evident why Central Asian states adopted a Soviet-style political and economic system after 1991. Moreover, its effects on their political system economy and overall governance reveal the whole story. The theory of Resource Curse depends on a single variable of consolidated interests to prove the case. However, it does not discuss how the political elite overcome their mutual differences and disagreements. This debate of resource curse unfolded in the 1950s and 1960s to examine the impact of resources on low to middle-income level states (Ross, 1999). However, the term "Resource Curse" was introduced by Professor Richard Auty in 1993 after the emergence of a resource-rich region in Central Asia (Perry, 2010).

\section{Resource Curse in Central Asia: Economic Implications}

The 'resource curse' theory explains a situation whereby states who are over-reliant on the export of natural resources, and it generates huge revenues for the government, constitute a paradox of political instability and economic stagnation. Therefore, the hydrocarbon resources and other raw materials are regarded as a curse for these states (Weinthal\& Loung 2010). The role of natural resources is undeniable in the economic growth and development of states around the world. Yet their impact on the development process is still ambiguous, which might turn out to be positive as well as negative. Some research studies argue that natural resources have less impact of a curse and have a pivotal impact on the outstanding economic and political development of Norway and Australia. However, the experience of the Post-Soviet states of Central Asia and Russia have been disparate, and Institutional development was compromised to achieve economic growth (Melony \& Lederman, 2007). While Angola and Sierra Leone in Africa illustrate an entirely negative image. Natural resources provoked large-scale violence and inflicted a terrible impact on society in Africa. Thus, an in-depth understanding of the impact of resources on the political-economic situation, and the solution to the problems 


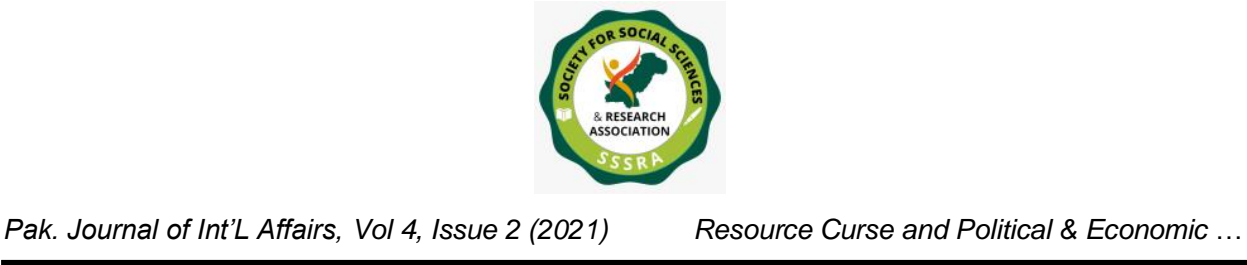

arising out due to resource dependence is a prerequisite for a smooth political and economic development in the resource-rich but underdeveloped states (Clark, 2011). International Monetary Fund data reveal that the number of declared resource-rich states is 51, and among them, 29 states are included in the category of low - and lower-middle-income states. Petroleum resources contribute approximately $50 \%$ share in their national income and 20\% in their exports (IMF, 2010). The list includes Central Asian states as well. Some common characteristics of these states include

(i) Thir acute dependency on the natural resource for either exports or fiscal revenues, or both (Venables).

(ii) Low rates of national savings with indigent economic growth

(iii) Highly capricious revenue generation.

(iv)

In Resource Curse, the over-dependence on exports of natural resources and raw material contradicts the economic growth. This scenario demonstrates the attributes of these newly established states by evaluating their economic structure. Their government gains a surplus revenue by exporting their natural resource. They do not rely on taxes from the masses for collection and the generation of revenues which are redistributed in the same sector.

\section{Dutch-Disease}

The resource curse creates the problem of biased growth. A top-down trend emerges here that leads to Dutch-Disease. The export of raw materials becomes the top priority of the governments. Thereupon, maximum factors of production switch from industries to one specific sector mostly the energy sector (Kiev, 2014). Hence, the nonenergy-based sector gets repudiated. This puts the other industries at a great disadvantage. It leads to a change and public behavior too who starts preferring the energy sector as the most beneficial and profitable sector of the economy. Therefore, a country's capital and most of the labor forces get concentrated around the energy sector. One of the grave consequences of this trend is that it divests the manufacturing sector from its indispensable resources. Eventually, it ends up with de-industrialization. In other words, it is called Dutch disease (Egert \& Leonard, 2008).

Dutch Disease infected states significant issues in economic development. Financial growth becomes highly inconsistent and susceptible. Particularly, at a time when the energy sector and resource income depletes, it creates severe unemployment. Such 


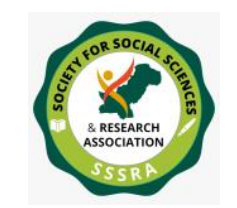

Resource Curse and Political \& Economic ...

states preferably employ resources from other sectors of the economy to generate employment opportunities and artificially control the loss of employment in the domestic market. It enables them to raise income and generate more revenues to be spent on social welfare, education, health, infrastructural development, and military spending (Egert \& Leonard, 2008). This trend has been visible in three Central Asian states, Kazakhstan, Turkmenistan, and Uzbekistan. After taking up all such measures, if the economy does not exhibit progress, becomes corruption and inefficiency, it left the country in economic chaos (Kiev, 2014). Contrary to this, if the economy performs better, it might lead to uplift economic competitiveness and generated revenues might provide as a wage subsidy.

Figure 1: Resource Curse

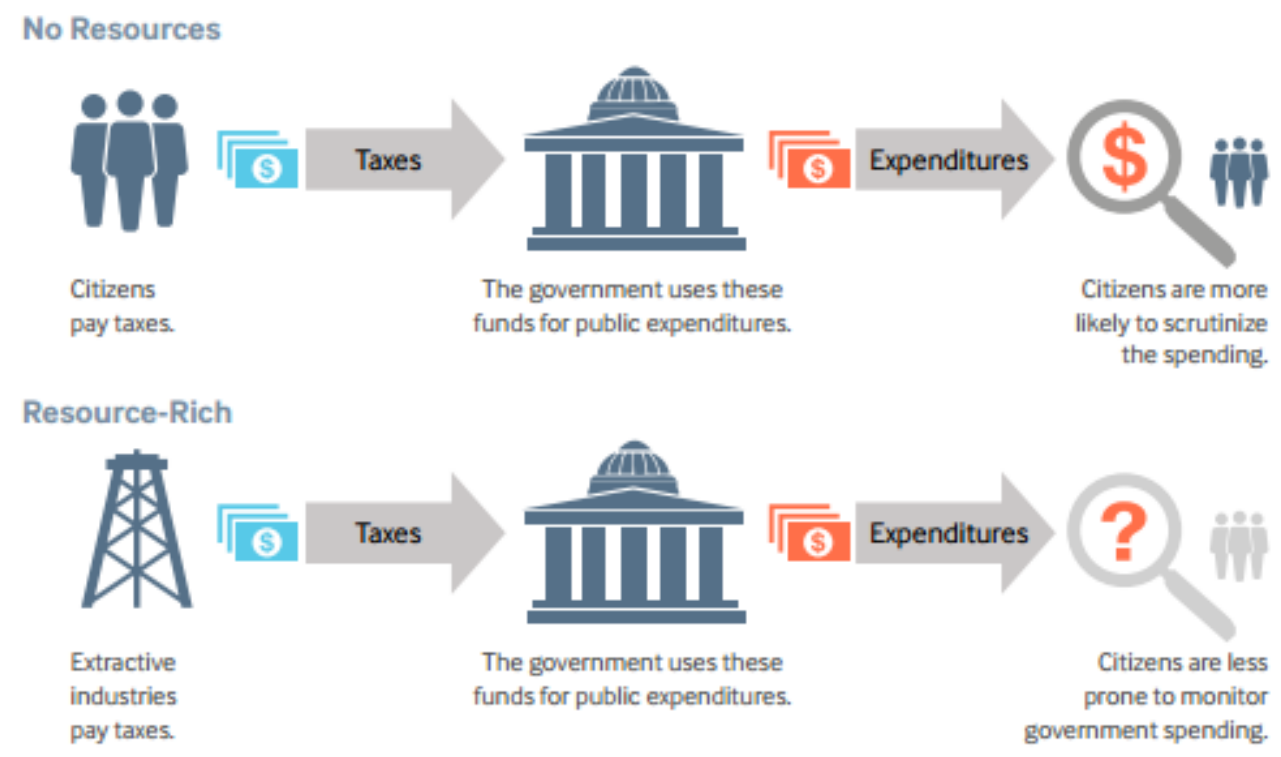

Source: (Natural Resource Governanace Institute, 2015)

Another implication of such a strategy is that it dwindles the internationally competitive and performing sectors of the economy. Consequently, the economy becomes more dependent on resource income. Fluctuating prices of resources especially, oil and gas put the economy in a highly vulnerable situation and may lead to economic disaster if not managed efficiently (Shaffer \& Ziyadov, 2012).

Many research studies support this idea that has proved that natural resources have become a prime factor in causing Dutch Disease. This is equally applicable to the post-Soviet states of Russia and Central Asia. Referring to a research study conducted to find out whether Dutch Disease has affected the Russian economy,

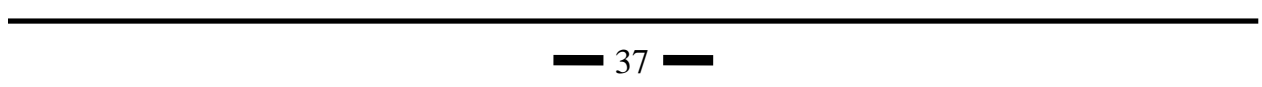




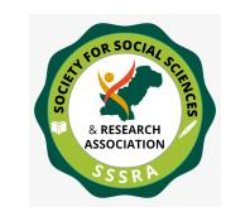

Pak. Journal of Int'L Affairs, Vol 4, Issue 2 (2021)

Resource Curse and Political \& Economic ...

establishes that it possesses all the discernable patterns of Dutch disease (Gelman \& Marganiya, 2010).

In addition to this, another research study to find out the impact of Dutch disease on Kazakhstan's inflation patterns confirms the above outcomes. Moreover, Leonard and Egert take up the case of Kazakhstan to examine its economic and political conditions to trace the Dutch disease in Kazakhstan (Egert \& Leonard, 2008). Above mentioned studies are just a few examples. Many other studies undertook the case of Central Asia and demonstrated a link between resources and Dutch disease in the regional states.

\section{Political \& Economic Ramifications of Resource Curse}

Many studies demonstrate that natural resources especially hydrocarbon resources weakens and nethers the development of democratic institutions and invigorate authoritarianism. A research study conducted in 2014, affirms the unfavorable impacts of oil (hydrocarbon resources) on the process and development of democratization. Resource economies have an adverse effect on political developments and democratization (Ahmadov, 2013).

In substance natural resources contribute to cohesion and augment the autocratic regime, withstanding a transition from authoritarian regimes to a democratic state. This is especially true for the oil and gas-rich states. A number of studies reinforce this theory. However, the notion of crippling democracies as an impact of resources is not well supported by most of the researchers. However, a mass level response to aforesaid authoritarianism and fragile democracy is quite insubstantial (Patrick, 2012). The Central Asia region presents a perfect case in this scenario where it has come up as a lucrative activity to facilitate their masses with exceptionally low taxes to prevent political ramifications of authoritarianism. Contrarily, states with less resource wealth, who impose massive taxes on their masses, receive strong demand for a corruption-free, competent and democratic government as well as accountability. It emerges as a perpetual bargain between the state and its citizenry.

In resources-rich economies, natural resources provide a reliable and regular source of income and governments do not feel it necessary to impose a tax on their citizens for regime stability (Richardson, 2015). Consequently, citizens do not exhibit much interest and watchfulness in the government's economic performance. Furthermore, governments in mineral resource-rich states do not feel endangered by civil service and civil society (Ross M. L., 2011). This helps in regime stability in such states. 


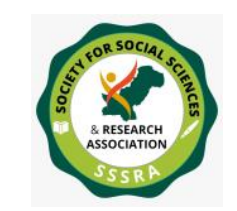

Pak. Journal of Int'L Affairs, Vol 4, Issue 2 (2021)

Resource Curse and Political \& Economic ...

This phenomenon is widely observed in Central Asia. Natural resource income empowers the authorities to respond in a persuasive manner against any unpleasant behavior or complaint from the masses. This is especially observed when the government gets failed to generate enough revenues due to an unexpected change in petroleum prices at the international level (Friedman, 2009). It has severe consequences and direct bearing on human rights, freedom of speech, etc.

This situation raises many questions like, how the authoritative regimes and their leadership see themselves in society? It emerges out that there is a feeling of insecurity in the governments of countries affected by the resource curse. As they are unable to set viable social and economic goals before them. It also adversely affects their ability to govern. This phenomenon is called governmentality, their assumption, and ideas that specify the relation between governments role and its policies to resolve the societal issues. Its fundamental objective is to actuate the regulations of the government. Consequently, the government acquires legitimacy and mass support. It also solidifies the democratic credentials strengthening the overall political structure. It is imperative to establish a discourse between the government institutions. It is also important to communicate it to the public. Only in this way, the government not only find feedback but also justification for its policies (Dean, 1999). The Central Asia governments are devoid of this approach.

A paradox emerges here. Although, Central Asian states failed to develop coordination among government institutions. They still desire substantial outcomes of their policies. The government in these states does not receive public response towards their policies due to the lack of communication with the public. Even then long for public support. Moreover, all of them are desirous of developing a democratic credential politically and open market economy with the tools of authoritarianism. Every Central Asian state has adopted a discursive approach. A state is not only considered a moral authority but also demonstrates its willingness to safeguard the interests of its people. However, a contradictory approach is adopted in Central Asia at the practical level and portrays democracy in such a negative manner that it is unable to overcome social inequalities and economic issues. In this way, the regime and system stability are emphasized (John, 2011). They adopt a managerial approach to run the government and postulate that leadership change might result in severe political and economic destabilization. This creates a feeling of dependence on the existing political and economic system and they assume that regime stability is synonymous with economic stability and security. 


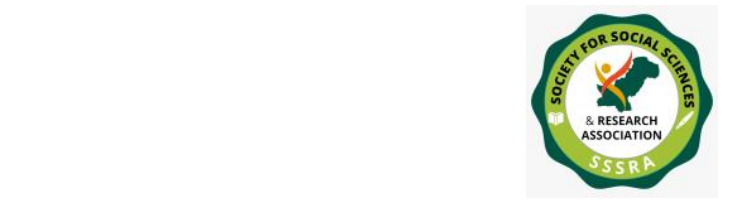

Pak. Journal of Int'L Affairs, Vol 4, Issue 2 (2021)

Resource Curse and Political \& Economic ...

Besides, another significant consideration for the elites in seeking the stability of such a system is to have direct access to states' economic resources. It assists them to maintain their economic clout and strengthen. According to a report, Kazakh President owns approximately US\$ 7 billion worth of financial assets (Swami, 2010). Moreover, increased natural resource revenues and the robust patronage system, result in the concentration of wealth among the fifty wealthiest Kazakh nationals, equal to US\$24 billion. Burgeoning political power is the foremost consequence of this wealth concentration (Malashenko, 2014). Likewise, Islam Karimov's rule in Uzbekistan is yet another illustration of this phenomenon. Karimov has been ruling his country since its independence until his death. In the 2015 election, he gained an overwhelming majority by obtaining $90 \%$ of the vote. In addition, his wealth estimates around US\$ 1 billion (SCMP, 2015). Similarly, Turkmen president, Gurbanguly Berdymukhamedov, has gathered huge sums from the natural gas trade-based economy. He has also acquired lavish gifts from many foreign investors. For instance, Russian firm Itera presented him with an expensive yacht worth US\$ 75 million in exchange for deals in the energy sector. Tajikistan presents a similar account. A leaked cable from some US diplomatic channels revealed the establishment of an offshore firm by the President of Tajikistan, Emamoli Rehmanov (Harding, 2010). For this purpose, huge financial resources were diverted from a state-owned firm to his exclusive funds.

The centralized electoral system is an avoidable aspect of politics in Central Asia. In the absence of an insignificant political resistance, the pseudo opposition fails to play any consequential role in the election. This invites a huge criticism from many critics who surprisingly inquire about the causes of such a meager response of the People of Central Asia to such autocratic rule. There have been soaring criticism of their electoral practices and political process that does not conform to international norms (Kubicek, 1998). Authoritarianism, as a common feature of all Central Asia along with resource-based economies and weakly embedded democracy, questionable human rights records all indicative of resource curse of which Central Asia presents a classic example.

\section{Conclusion}

The resource curse theory has some interesting compatibility with the situation in the Central Asia region and provides an interesting case to study. It demonstrates that only an economic and theoretical guide is not enough to understand the Central Asia region. This study finds two parallel but equally contradictory paradigms of regional economies and politics. The theoretical explanation through the prism of 


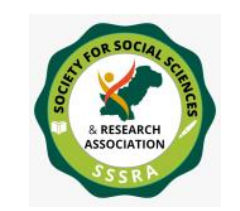

Pak. Journal of Int'L Affairs, Vol 4, Issue 2 (2021)

Resource Curse and Political \& Economic ...

the resource curse elaborates how a specific economic structure obstructs the democratic development in this region. The governmental approach towards domestic political, economic, and social issues produces a rationale for adopting an aforementioned authoritative system of government in Central Asian Republics. The democratic development in the region is greatly hampered due to the prevailing economic structure. The managerial approach adopted in these states to run state affairs has increased suspicions about democracy among the masses. This is one of the most important features of this system. In addition, resource extraction, and its export are the focus of economic activity along with the redistribution of resources earning by business clans and their patronage networks. They are a great source of stability to the authoritative Central Asian regimes. In the absence of tax income, the highly centralized structure of government is heavily dependent on the exports of these mineral resources and raw materials. This remarkably curtails the public's ability to demand accountability. Overemphasis on one sector like raw minerals extraction and export averts the development and growth prospects in the other sectors of the economy. Therefore, in this scenario, change of leadership, accountability, and democratization become an uphill task and threatens the stability of the state.

Moreover, strong institutions and their development are desired in these states despite the deficient communication between government and masses and less coordination between different government institutions. Natural resources have turned out to be a curse for the former Soviet states of Central Asia because it has strengthened authoritarianism. Ironically, they have been struggling to develop democracy and a liberal economy by providing stability to these authoritative regimes. The establishment of an open market economy is still a far cry for the Central Asian states unless they initiate the process of decentralization of their political and economic system. They require a complete overhauling of their political and economic system to meet the goal of establishing an open market economy and its real impact on the development of a democratic political system. 


\section{References}

Ahmadov, A. K. (2013). Oil Democracy and Context: A Meta Analysis. Journal of Comparative Politics, 47(9), 1238-1267. doi:https://doi.org/10.1177/0010414013495358

Algozhina, A. (2006). "Inflation Consequences of Dutch Disease” in Kazakhstan: The Case of Prudent. Graduate Institute for Policy Studies.

Asian Development Bank. (2019). Governance and Development Outcomes in Asia. Retrieved January 2, 2020, from https://www.adb.org: https://www.adb.org/publications/governance-and-development-outcomes-asia.

B.B. (2011, April 5). Outdoing himself. Retrieved December 10, 2016, from http://www.economist.com/: http://www.economist.com/blogs/banyan/2011/04/kazakhstans_presidential_electio $\mathrm{n}$

Brinks, D., Leiras, M., \& Mainwaring, S. (2014). Reflections on Uneven Democracies: The Legacy of Guillermo O' Donnel. (D. Brinks, M. Leiras, \& S. Mainwaring, Eds.) Baltimore: JohnHopkins University Press.

Buranbayeva, L. (1996). Economic Transition in Russia and the New States of Eurasia (Vol. 8). (B. Kamiński, Ed.) New York, USA: Routledge.

Buyers, L. M. (2003). Central Asia in Focus: Political and Economic Issues. New York: Nova Publishers.

C.S, E. B. (2007). Dutch Disease Scare in Kazakhstan: Is it real?”. William Davidson Institute.

Clark, H. (2011, October 20). Avoiding the resource curse: Managing extractive industries for Human Development. Retrieved December 9, 2016, from http://www.undp.org/: http://www.undp.org/content/undp/en/home/presscenter/speeches/2011/10/20/helen -clark-avoiding-the-resource-curse-managing-extractive-industries-for-humandevelopment-.html

Cummings, S. (2010). Domestic and International Perspective in Kyrgyzstan's Tulip Revolution: Motives, Monilization and Meaning. New York: Routledge Publishers.

Dean, M. (1999). Governmentality:Power and rule in Modern Society. Los Angeles: Sage Publisher. 
Doorenspleet, ,. R. (2008). Upping the Odds: Deviant Democracies and Theories of Democratization. Democratization, 815-832.

Egert, B., \& Leonard, C. S. (2008). Dutch Disease in Kazakhstan: Is it real? Journal of Open Economic Review, 19(2), 147-165. doi:https://doi.org/10.1007/s11079-0079051-7

Ekiert, G. (1991). Democratization Processes in East Central Europe: A Theoretical Reconsideration. British Journal of Political Science, 285-313.

Friedman, T. L. (2009, October 16). The First Law of Petropolitics. Retrieved December 10, 2016, from https://foreignpolicy.com/: http://foreignpolicy.com/2009/10/16/thefirst-law-of-petropolitics/

Gelman, V., \& Marganiya, O. (2010). Resource Curse and Post Soviet Eurasia: Oil, Gas and Modernization. Maryland: Rowman \& Littlefield Publisher.

Harding, L. (2010, December 12). Retrieved December 10, 2016, from https://www.theguardian.com: https://www.theguardian.com/world/2010/dec/12/wikileaks-bleak-picture-tajikistan

Harding, L. (2010, December 12). Wikileakes cables paint bleak picture of Tajikistan, Central Asia's poorest state. Retrieved from https://www.theguardian.com: https://www.theguardian.com/world/2010/dec/12/wikileaks-bleak-picture-tajikistan

Harding, L. (2010, December 2). WikiLeaks cables: Turkmenistan president wanted yacht like Abramovich. Retrieved December 10, 2016, https://www.theguardian.com/world/2010/dec/02/wikileaks-cables-turkmenistanpresident-yacht

IMF. (2010, October 10). Resource Rich Countries Can seize Opportunities. Retrieved December 28, 2019, from https://www.imf.org: https://www.imf.org/en/News/Articles/2015/09/28/04/53/socar101012a

$I M F$. (2012, October 12). Retrieved from www.imf.org: https://www.imf.org/en/News/Articles/2015/09/28/04/53/socar101012a

John, J. D. (2011). Is There Really a Resource Curse? A critical Survey of Theory and Evidence. Journal of Global Governance, 17(2). doi:https://www.jstor.org/stable/23033728.

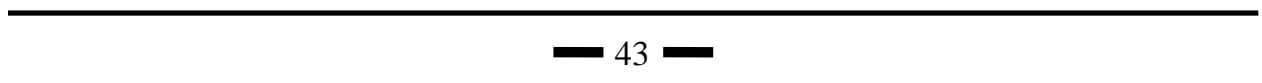


Resource Curse and Political \& Economic ...

Khan, D. S. (2008). Economic Transition in Central Asia. Journal of Central Asia, Russia, China University of Peshawar, 1-4.

Kiev, C. W. (2014, November 5). What Dutch Disease is, and why its bad? Retrieved January 27, 2020, from https://www.economist.com: https://www.economist.com/the-economist-explains/2014/11/05/what-dutchdisease-is-and-why-its-bad

Kubicek, P. (1998). Authoritarianism in Central Asia: Curse or Cure? Journal of Third World Quarterly, 19(1), 29-43. doi:https://doi.org/10.1080/01436599814514

Kunal, S. (2014). Governance and Development Outcomes in Asia. Manila: Asian Development Bank.

Leiras, M., Mainwaring, S., \& Brinks, D. (2014). Reflections on Uneven Democracies: The Legacy of Guillermo O' Donnel. (D. Brinks, M. Leiras, \& S. Mainwaring, Eds.) Baltimore: JohnHopkins University Press.

Loung, P. J., \& Weinthal, E. (2010). Oil Is Not a Curse Ownership Structure and Institutions in Soviet Successor States. New York: Cambridge University Press.

Malashenko, A. (2014, July 16). Exploring Uzbekistan's Potential Political Transition . Retrieved from https://carnegie.ru: https://carnegie.ru/2014/07/16/exploringuzbekistan-s-potential-political-transition-pub-56169

Malcolm Dowling, G. W. (2006, July). Central Asia's Economy: Mapping Future Prospects to 2015. Retrieved February 2, 2020, from https://www.silkroadstudies.org: https://www.silkroadstudies.org/resources/pdf/SilkRoadPapers/2006_07_SRP_Dow nlingWignaraja_Central-Asia-Economy.pdf

Markowitz, L. P. (2013). State Erosion: Unlootable Resources and Unruly Elites in Central Asia. London: Cornell University Press.

Mclean, W. (2015). Authoritarianism, Energy and Ideas in Central Asia: From Politics and Pipelines to Foreign Policy. London: Palgrave Macmillan.

Mclean, W. C. (2015). Russia, Eurasia and the New Geopolitics of Energy. London: Palgrave Macmillan. 


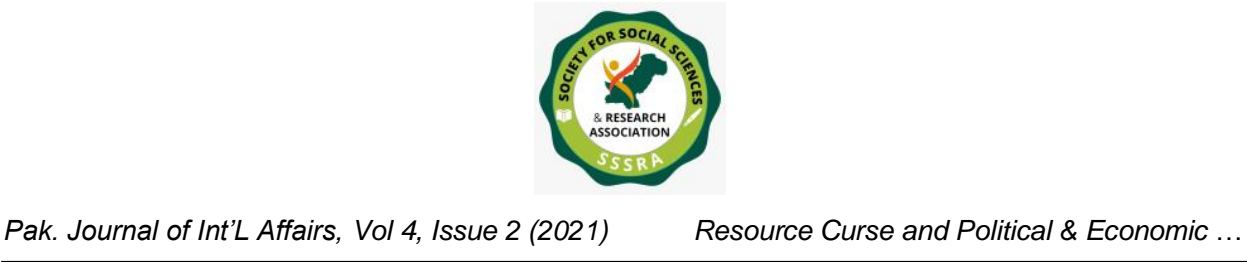

Melony, D., \& Lederman, W. F. (2007). Natural Resources, Neither Curse nor Destiny. Washington: Stanford University.

Melvin, M. J. (2000). Uzbekistan to Authoritarianism. Amsterdam: Harwood Academic Publishers.

Moore, M. (2004, July 25). Revenues, State Formation, and the Quality of Governance in Developing Countries. International Political Science Review, pp. 297-319.

Morrison, K. M. (2009). Oil, Nontax Revenue, and the Redistributional Foundations of Regime Stability. International Organization, 107-138.

Natural Resource Governanace Institute. (2015, April 27). Retrieved from https://resourcegovernance.org: https://resourcegovernance.org/analysistools/publications/primer-resource-curse

Natural Resource Governance Institute. (2015, April 27). Primer: The Resource Curse. Retrieved from https://resourcegovernance.org:

https://resourcegovernance.org/analysis-tools/publications/primer-resource-curse

Omelicheva, M. Y. (2013). Democracy and Dictatorship in Central Asia. New York: Oxford University Press.

Omelicheva, M. Y. (2015). Democracy in Central Asia: Competing Perspective and Alternative Strategies. Kentuckey: The University of Kentuckey Press.

Oomes, N. a. (2007). Diagnosing Dutch Disease: Does Russia Have the Symptoms? IMF.

Patrick, S. M. (2012, April 30). Why Natural Resources are a Curse on Developing Countries and How to fix it? Retrieved January 29, 2020, from https://www.theatlantic.com:

https://www.theatlantic.com/international/archive/2012/04/why-natural-resourcesare-a-curse-on-developing-countries-and-how-to-fix-it/256508/.

Perry, A. (2010, June 28). Brief History: The Resource Curse. Retrieved December 30, 2019, from http://content.time.com: http://content.time.com/time/magazine/article/0,9171,1997460,00.html

Pickel, S. P. (2006). Political Culture and Democracy Research. Retrieved December 3, 2016, from https://www.uni-due.de/politik/pickel_publikationen.php 
Pomfret, R. (2006). The Central Asian Economies Since Independence. New Jersy: Princeton University Press.

Pomfret, R., \& Kathryn, A. (2001). Economic Development Strategies in Aentral Asia since 1991. Asian Studies Review, 25, 185-200.

Richardson, J. (2015). European Union: Power and Policy making. New York: Routledge Publishers.

Ross, M. L. (1999). The Political Economy of the Resource Curse. Camberidge Journal of World Politics, 51(2), 297-332. doi:https://doi.org/10.1017/S0043887100008200.

Ross, M. L. (2004). Does Taxation Lead to Representation. British Journal of Political Science., 229-249.

Ross, M. L. (2011). Does Oil Hinder Democracy? World Politics, 325-361.

Ross, M. L. (2015). What Have We Learned about the Resource Curse?". Annual Review of Political Science, 239-259.

Rumer, B. Z. (2005). Central Asia at the End of Transition. New York: M.E Sharp Publishers.

Rustemova, A. (2010). Political Economy of Central Asia: Initial reflections on the need for a new approach. Journal of Eurasian studies, 30-39.

Sachs, J. \&. (1995). Natural resource anudance and economic growth. Harvard: Harvard Institute of Economic Research.

SCMP. (2015, March 30). Veteran Uzbek Leader Karimove re elected in voteOSCE brands "undemocratic". Retrieved from https://www.scmp.com: https://www.scmp.com/news/world/article/1751676/uzbek-president-karimov-setextend-his-25-year-rule

Seifert, A. C. (n.d.). Retrieved from https://ifsh.de/: https://ifsh.de/fileCORE/documents/yearbook/english/11/Seifert-en.pdf

Shaffer, B., \& Ziyadov, T. (2012). Beyond the Resource Curse. Philadelphia: University of Pennsylvania Press. 


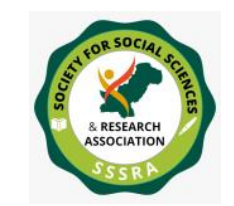

Resource Curse and Political \& Economic ...

Smith, M. L., \& Jones, D. M. (2015). The Political Imposibility of Modern Counterinsurgency: Strategic Problems, Puzzles and Paradoxes. New York: Columbia University press.

Solovyov, D. (2015, March 30). Veteran Uzbek leader re-elected in vote OSCE brands undemocratic. Retrieved December 10, 2015, from Reuters: http://www.reuters.com/article/us-uzbekistan-electionidUSKBN0MQ15A20150330

Swami, P. (2010, December 1). Nursultan Nazarbayev: The shepherd's son who became Kazakhstan's . Retrieved December 10, 2016, from http://www.telegraph.co.uk/: http://www.telegraph.co.uk/news/worldnews/wikileaks/8171617/NursultanNazarbayev-the-shepherds-son-who-became-Kazakhstans-Emperor.html

Swami, P. (2010, December 1). Nursultan Nazarbayev: The Shepherd's son Who Became Kazakhstan's Emperor. Retrieved from https://www.telegraph.co.uk: https://www.telegraph.co.uk/news/worldnews/wikileaks/8171617/NursultanNazarbayev-the-shepherds-son-who-became-Kazakhstans-Emperor.html

Tajikistan History/ Nationencyclopedia. (2017, February 25). Retrieved from http://www.nationsencyclopedia.com: http://www.nationsencyclopedia.com/Asiaand-Oceania/Tajikistan-HISTORY.html

Venables, A. J. (n.d.). 30(1). doi:https://www.jstor.org/stable/43710015?seq=1\#page_scan_tab_contents

Venables, A. J. ( 2016). Using Natural Resources for Development: Why Has It Proven So Difficult? Journal of Economic Perspectives, 161-184. .

Weinthal, P. J. (2010). Oil is Not Curse: Ownership Structure and Institutions in Soviet Successor States. New York: Camberidge University Press.

World Bank. (2019, December 30). GDP Data. Retrieved from https://data.worldbank.org/indicator/NY.GDP.MKTP.CD?locations=KZ.

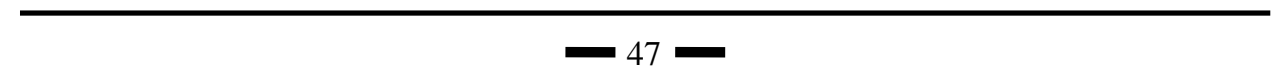

